\title{
Effect of Income, Population, Government Spending, Export Goods and Services of Regional Economic Sector in Indonesia
}

\author{
Fransiskus Xaverius Lara Aba \\ Department of Economics Finance and Banking, Atma Jaya Catholic University of Indonesia, Jakarta, Indonesia \\ Email address: \\ fransiskus.lara@atmajaya.ac.id
}

\section{To cite this article:}

Fransiskus Xaverius Lara Aba. Effect of Income, Population, Government Spending, Export Goods and Services of Regional Economic Sector in Indonesia. International Journal of Economics, Finance and Management Sciences. Vol. 6, No. 3, 2018 , pp. 75-81. doi: $10.11648 /$ j.ijefm.20180603.11

Received: October 18, 2017; Accepted: February 6, 2018; Published: May 22, 2018

\begin{abstract}
The results of data analysis for 25 years from 1991 to 2015 using regression models) showed that the value added of each economic sector in the State of East Indonesia was determined to be individually or by changes in per capita income. Thus according to the title Effect income, population, government spending, exports of goods and services to the primary sector of regional economic in East Nusa Tenggara Indonesia, a study was done to see the impact of per capita income, population, production empire and exports of goods and services to a core sector growth in East Nusa Tenggara Indonesia for development planning in the region? The objective of this study was to review and analyze the growth sectors of economy East Nusa Tenggara Indonesia to national economic growth, and effect of income per capita GDP, the total population of the government spending, exports of goods and services to growth in the primary sector, East Nusa Tenggara Indonesia. Analysis of growth and elasticity the display size of a correlation value added output of economic sectors due to changes in population and per capita income in region. The results of this analysis can be used to develop projections of economic growth rates and changes or shifts in economic structure in East Nusa Tenggara Indonesia. Emphasizes that GDP grew in the 1950s and 1960s [17]; [11] theory of economic growth can be achieved through capital investment or investment in large quantities in the industrial sector.
\end{abstract}

Keywords: Growth, Regional Economic, Elasticity, Planning, Economic Base

\section{Introduction}

Size growth elasticity analysis is one Form of analysis to show a relationship between gross added value due to changes in the economic sector of the population and income (Gross Domestic Product / GDP) per capita in the region. This analysis can then be used to develop projections of economic growth and structural change or shift in the economy of a region. Regression analysis was used to determine the effect of per capita income, government spending and exports to value added sector economic. The results of the regression analysis, either individually ( $\mathrm{t}>\mathrm{t}$ table) or together ( $\mathrm{F}>$ Table F), per capita income and government spending has a significant impact on gross added value of agriculture and the service sector.

Thus, it can be concluded that the export activity is not much to encourage the growth of the primary sector in East Nusa Tenggara Indonesia. This is because there are still many problems, such as overlapping regulations due to high transaction costs, thus reducing the competitiveness of businesses that have been running or even reduce the attractiveness of investments [1].

\section{Literature Review}

GDP showed only the economy of a region. It should not be used to assess the level of prosperity of the population in an area. Thus, income per capita, which is the average income divided by the total population of the region East Nusa Tenggara Indonesia is deemed appropriate indicators to assess the level of prosperity the population.

Networking between regions is becoming increasingly 
important in economic development, as it is able to control complex transactions as well as cooperation among firms in different region. Different studies show positive effects of networks between regions in the fields of activity, performance, and innovation [14]; [7]. Empirical study on trade facilitation is driven by the importance of economic relations [12]; [4]. According to [2] described the lack of economic and trade relations in region, especially lowincome countries as a hidden transaction costs, which can be associated with the exchange between nations. Transaction costs that are hidden in low income countries due to corruption, lax enforcement and crime.

[20] and the theory of economic integration such as [16]; [5]; [15]; [10] and [3] describe the technical progress as the effect of endogenous instead receiver neoclassical view. [21]; [8], describes technological changes related to competitiveness of the territory. [13]; [8]; [18] describes the product cycle, which can give a different effect on region through three stages, namely: level of innovation, growth and the level of standardization. [19]; [9] described the region as the economy macroeconomic model, $\mathrm{Y}=\mathrm{C}+\mathrm{I}+\mathrm{G}+(\mathrm{X}$ $\mathrm{M})$; The gross national product is equal to the expenditure for consumption, investment, government and net exports.

\section{The Methodology and Model}

Descriptive research methods used to get the facts about the study. Regional studies East Nusa Tenggara Indonesia's economic growth is measured by the increase in GDP in the first three months of 2014 experienced a contraction of $5.64 \%$ compared with the fourth quarter of 2013 (q-to-q) and when compared with the three months the same in 2013 grew by $5.02 \%$ (y-on-y). Household consumption expenditure hands on the first three months of 2014 compared with the fourth quarter of 2013 (qon q) decreased by $-1.92 \%$ correct; government consumption expenditure declined by $-25.88 \%$ fixed capital formation declined by $-17.99 \%$; exports of goods and services declined by $-15.13 \%$; and the import of goods and services declined by $-26.17 \%$ [6].

The data used in this study includes qualitative data and quantitative data. The qualitative data is obtained in the form of data is not a number, such as data on economic sectors and non-basic, condition and location of communities to climate studies. Meanwhile, quantitative data obtained in the form of numbers, such as GDP data, the result of government spending and other data in connection with the implementation of the study. Both types of data derived from primary data and secondary data. The primary data used to assess the views and information from stakeholders that have to do with policy planning and program implementation border area development program. Sources of primary data obtained through the respondents involved in this study. Primary data are descriptive, in the form of a table, documents and court records.

Meanwhile, secondary data include certain documents relevant to policy planning and implementation of program development program frontier region. Secondary data were used as a source in this study consisted of data resident, estimates and state income, GDP data, the Gross National Product (GNP) data on GDP per capita, GDP data central government spending data the government with its utilization and data exports of goods and services in use. East Nusa Tenggara Indonesia for a series of time is 25 years, then the data collected for period $1991-2015$, [6].

Model analysis of this study covers macro-economic problems East Nusa Tenggara Indonesia including:

\subsection{Model Analysis of Structure and Regional Economic Growth in GDP}

Regional economic structure is analyzed based on the contribution of each sector relative to total GDP in East Nusa Tenggara Indonesia. While economic growth in the GDP for 25 years (1991-2015) is calculated based on the equation of an exponential trend. Form the equation is as follows:

$$
\mathrm{Yt}=\mathrm{aeb}(\mathrm{t}-1) \text { or } \mathrm{Yt}=\mathrm{aebx}
$$

$$
\mathrm{e}=2,71828
$$

$t=$ variable Time

$\mathrm{x}=$ Variable Time - in the middle of the period under review

$\mathrm{b}=$ rate of change of the variables Yt per year

$a$ and $b$ are the values of the coefficient is sought from time series data with data pairs $(\mathrm{X}, \mathrm{Y})$. The $\mathrm{a}$ and $\mathrm{b}$ are obtained by using the properties of logarithms to help explain the preparation of an exponential trend equation.

To see GDP in the future with an important sector in the GDP estimate for next five or ten years into the future is to use multiple regression analysis with the following equation:

$$
\mathrm{Yt}=\mathrm{a}+\mathrm{biXi}+\mathrm{b} 2 \mathrm{X} 2+\mathrm{b} 3 \mathrm{X} 3
$$

$X i=$ the value of the projected sector $\mathrm{i}$ in year $\mathrm{t}$

$a=$ constant coefficient in $\mathrm{t}$

$b=$ regression coefficient of variable $\mathrm{X}$

$X 1=G N P$

$X 2=$ variable dummy $0=$ before the crisis, and 1 for a period of economic crisis

$X 3=$ labor

\subsection{Regression Analysis Model}

This analysis is an analysis of the relationship of gross value added of an economic sector as a result of changes in population and income per capita.

Form equation is:

$$
\operatorname{Ln} \mathrm{Xi}=\alpha+\beta \operatorname{Ln} \mathrm{Y} / \mathrm{cap}+\lambda \operatorname{Ln} \text { Pop }
$$

$\alpha=$ constant

$\beta=$ elasticity of growth $i$, means a coefficient expressing the percentage of Gross Value Added i

Sector due to the per capita income of $1 \%$;

$\lambda=$ Elasticity magnification sector $i$, means a coefficient expressing the percentage of Gross Value Added East Nusa Tenggra Indonesia sector $i$ as a result of population increase 
by $1 \%$;

$\mathrm{Xi}=$ sector $\mathrm{i}$;

$\mathrm{Y} /$ cap = Income per capita;

Pop = Total population;

From the regression equation sharing displacement shift share and growth can be concluded that: (1). Elasticity growth is the percentage change in GDP per capita leads to a certain sector or a change in the value added per capita GDP increase of 1 percent, which resulted in certain changes in the value added sector of X.; (2). Elasticity enlargement is the percentage change in the number of people who cause change certain sector or 1 percent population increase which resulted in certain changes in the value added sector of X.

Understanding growth and scale: (1). When the elasticity is equal to 1 (one), it is known as unitary elasticity, ie when the total population or $1 \%$ of per capita income that result in changes in the value added of a particular sector also 1 percent.; (2). When the elasticity is less than 1 (one), it is known as inflexibility (inelasticity), ie when the change of population or per capita income by 1 per cent change in the value added which resulted in certain sectors also less than $1 \% .1 \%$ change in the value added which resulted in certain sectors more than $1 \%$.

\subsection{Regression Analysis Model Sector Base}

Regression analysis was used to look at the basic sectors of per capita income, government spending and exports of goods and services on the growth of the primary sector in East Nusa Tenggara Indonesia. The equation for the regression of the primary sector can be summarized as follows:

$$
\operatorname{LnYi}=\beta 0+\beta 1 \operatorname{LnX} 1+\beta 2 \operatorname{LnX} 2+\beta 3 \operatorname{LnX} 3
$$

LnYi = Value Added Gross Basis sector i;

$\mathrm{X} 1=$ Income per capita;

$\mathrm{X} 2$ = Government Spending;

X3 = Exports of Goods and Services;

$\beta \mathrm{o}=$ Constant (Intercept);

$\beta 1=$ elasticity of growth $i$ due to changes in the primary sector budget allocation of $1 \%$

$\beta 2=$ Elasticity growth due to changes in primary sector $\mathrm{i}$ per capita income growth of $1 \%$

$\beta 3$ = Elasticity growth due to changes in the primary sector i Nefai export growth by $1 \%$

When the elasticity of more than 1 (one), it is known as elasticity (Elasticity), ie when changes in population or per capita income by $1 \%$.

\subsection{Regional Economic Growth Model}

Model Based Export In this model, the GDP income can be expressed as follows:

$$
\mathrm{Y}=\mathrm{C}+\mathrm{MI}-\mathrm{MO}
$$

$\mathrm{Y}=$ income regions (GDP),

$\mathrm{C}=$ Consumption,

$\mathrm{MI}=$ Flow of money coming in because their exports

$\mathrm{MO}=$ Flow of money out because of their imports.
For convenience, use is considered linear function, so it can be written as:

$$
\mathrm{C}=\mathrm{A}+\mathrm{b} \mathrm{Y}
$$

$\mathrm{A}=$ minimum usage

$\mathrm{b}=$ MPC (Marginal Propensity to Consumer).

Given the lack of entrepreneurs in developed countries that invest abroad and the results brought to the region, the export is the only source of foreign currency income, which can be formulated as follows:

$$
\mathrm{MI}=\mathrm{Eo}
$$

EO is export fluctuations are determined by external factors (exogenous), as the prices in the international market. As most foreign investment is limited, then the only source of money out of imports, which could be formulated as follows:

$$
\mathrm{MO}=\mathrm{i} \mathrm{Y}
$$

By combining equations (5) - (8), we get the following equation:

$$
\begin{aligned}
& Y=A+b Y+E O-i Y \\
& \text { Or } Y=[1 /(1-b+i)](A+E O)
\end{aligned}
$$

Because the debate is related to growth, then the equation (9) can be formulated in the form of change $(\Delta)$ as follows:

$$
\Delta \mathrm{Y}=[1 /(1-(\mathrm{b}-\mathrm{i})] \Delta \mathrm{Eo}
$$

Or

$$
\Delta \mathrm{Y}=\mathrm{k} \Delta \mathrm{Eo}
$$

Here $\mathrm{k}=[1(1-(\mathrm{b}-\mathrm{i})]$ is the multiplier that reflect the multiplier effect of the change in exports to the regional economy.

\subsection{Economic Base Model}

Export base model can also be formulated as Economic Base Model. In this case, the economy of a region $(\mathrm{Y})$ can be divided into two main sectors, namely Sector Basic (B) and Non Basic Sector (S), and can be summarized as:

$$
\mathrm{Y}=\mathrm{B}+\mathrm{S}
$$

Activities supporting the sector would largely depend on development of primary sector, which allows it formulated as:

$$
\mathrm{S}=\mathrm{ao}+\mathrm{a} 1 \mathrm{Y}
$$

Here, ao and a1 are constants. When the equation (12) is inserted into the equation (11), obtained the relationship between the sector and supporting basic sectors as follows:

$$
\mathrm{Y}=[\mathrm{ao} /(1-\mathrm{a} 1)]+[1 /(1-\mathrm{a} 1)] \mathrm{B}
$$

and 


$$
\mathrm{Y}=[\mathrm{a} 0 /(1-\mathrm{a} 1)]+[\mathrm{B} /(1-\mathrm{a} 1)]
$$

Because equation (14) is linear, the coefficient multiplier must be calculated in the form of regional economic growth equation as follows:

$$
\Delta \mathrm{Y}=[\mathrm{a} 0(1-\mathrm{a} 1)]+[1 /(1-\mathrm{a} 1)] \Delta \mathrm{B}
$$

Here, $\Delta \mathrm{Y}$ is the increase in GDP and $\Delta \mathrm{B}$ is the increase in the basic sectors. This equation gives the conclusion that the economic growth of a region is determined by the development of sector and the large base of small effect are determined by the coefficient multiplier $[1 /(1+$ ao $)]$. Thus, based on this model, it can be hypothesized that the economic growth of a region is positively associated with increased exports.

\section{Analysis of the Planning and Growth Elasticity}

In economic field, this concept can be used to understand the impact of such a policy. In addition, it can also be used to analyze the impact of revenue increase of production areas. Analytical tool to assist policy makers in deciding priorities and alternative development plans that provide the greatest benefits for regional development. This analysis can then be used to develop projections of economic growth and structural change or shift in the economy of a region. Table 1 below shows the results of regression analysis the effect of per capita GDP and population to value added economic sectors East Nusa Tenggara Indonesia during 1991-2015.

Table 1. Regression Analysis of the Effect of GDP Per Capita and Population the Economic Value Added Sector East Nusa Tenggara Indonesia in the period

\begin{tabular}{|c|c|c|c|c|}
\hline \multirow{3}{*}{ Sector } & \multicolumn{4}{|c|}{ Regression Analysis } \\
\hline & \multicolumn{2}{|c|}{ Table $t=1.72$ Count $t$} & \multirow{2}{*}{ Table $F=3.44$ Count $F$} & \multirow{2}{*}{$\mathbf{R}^{2}$} \\
\hline & GDP Per Capita & Population & & \\
\hline Agriculture & 5.89 & 1.65 & 273.56 & 0.9613 \\
\hline Mining and Quarrying & 4.38 & -0.24 & 84.58 & 0.8849 \\
\hline Manufacturing & 4.35 & 0.22 & 102.08 & 0.9027 \\
\hline Electricity, Gas and Water Supply & 2.97 & 0.86 & 70.51 & 0.8650 \\
\hline Trade, Hotel and Restaurant & 5.96 & 2.90 & 375.14 & 0.9715 \\
\hline Transport and Communications & 3.84 & 1.68 & 146.17 & 0.9300 \\
\hline Finance, Leasing and Services Company & 3.39 & 1.47 & 113.49 & 0.9116 \\
\hline Services & 5.05 & 2.40 & 265.67 & 0.9602 \\
\hline
\end{tabular}
$1991-2015$.

Analysis found that the value added sector of economy of East Nusa Tenggara Indonesia is influenced by variables GDP per capita. This situation is reflected in the value of the count variable $t$ GDP per capita greater than the value $t$ table (1.72) for every sector of the economy. The results of data analysis for 25 years from 1991 to 2015 by using economic regression model (Table: 1 ) showed that the value added of each economic sector in East Nusa Tenggara Indonesia was determined to be individually or by changes in per capita income. It is stamped on $t$ test results, the table $t$, a 95 percent and 22 independent degrees smaller than the count value $t$, the variable income per capita. The variables for the total population only have an effect on value added trade, hotels and restaurants and service sector.

Generally, it was found that variables GDP per capita and the number of individual influence on value-added trade, hotels and restaurants, as well the services sector. T count value for each variable is GDP per capita and population in the two sectors is greater than the value $t$ table. For the trade, hotels and restaurants, the count value $t$ variables GDP per capita is 5.96 and variables total population is 2.90. For services sector, the count value $\mathrm{t}$ variables GDP per capita is 5.05 and variables total population is 2.40 .

The analysis results of study showed that variables of population individually have no effect on the value-added agriculture, mining and quarrying, manufacturing, electricity, gas and water supplay, construction, transport and communications sector and the financial sector, leasing and service company. $\mathrm{T}$ count the variables total population of the seven sectors showed a smaller value than the value $\mathrm{t}$ table (1.72).

According to Table 4, variables GDP per capita and population variables jointly affect the value added of all economic sectors. F count value for all sectors of the economy exceeds the schedule F (3:44). Thus, it can be concluded that the contribution of variables GDP per capita and a variable number of the value added of all economic sectors showed considerable and variable. This is evident based on the value of $\mathrm{R} 2=0.9613$ agricultural sector, which means that the contribution of variables GDP per capita and a variable number of the value added agricultural sector is $96.13 \%$.

On the other hand, the balance of $3.87 \%$ is another variable contribution to value added of the agricultural sector. $\mathrm{R} 2=0.8849$ for the mining and quarrying sector means that contribution of the variables GDP per capita and a variable number the value added of this sector amounted to $88.49 \%$. Rather, balance of $11: 51 \%$ is another variable contribution to value added mining and quarrying sector. The high value of R2 for every sector of the economy showed that in variables GDP per capita and a variable number of the population has a very large contribution to value added economic sectors of East Nusa Tenggara Indonesia. 


\section{Regression Analysis Sector Planning Basics}

Characteristics of region refer to the problems and potentials of region. Development plans aimed at managing human resources so as to support the economic development of the region East Nusa Tenggara Indonesia, based on regression analysis of the basic sectors like below.

Table 2. Regression Analysis Effect Per Capita GDP, Government Spending and Exports of Goods and Services for Value Added Sector of Region East Nusa Tenggara Indonesia Basic Economic the Period 19991-2015.

\begin{tabular}{|c|c|c|c|c|c|}
\hline \multirow{3}{*}{ Sector } & \multicolumn{5}{|c|}{ Regression Analysis } \\
\hline & \multicolumn{3}{|c|}{ Table t $\alpha 0.05=1.72$ Count $t$} & \multirow{2}{*}{ Table F $\alpha 0.05=3.47$ Count F } & \multirow{2}{*}{$\mathbf{R}^{2}$} \\
\hline & GDP Per Capita & Spending Government & Export Goods and Services & & \\
\hline Agriculture & 12.01801 & -2.037500 & 1.239599 & 116.2941 & 0.943 \\
\hline Services & 8.80934 & -1.169107 & 1.704240 & 72.17347 & 0.911 \\
\hline
\end{tabular}

According to Table 2 show that GDP per capita variables have an influence on the value-added agriculture and services sectors. This is evident based on the count value $t$ variables GDP per capita for each sector (2.12 and 8.81) greater than the value $t$ table (1.72). While government expenditure variables individually have no effect on the value-added agriculture and services sector, the value of the count variable $t$ government spending for each sector (-2.04 and -1.17) is smaller than the value $\mathrm{t}$ table (1.72). Similarly, the variable expenditure of government, the variable export of goods and services, which has no effect on the value added of the agricultural sector and the services sector, which the count value $t$ variable export of goods and services for each sector (1.24 and 1.70) is smaller than the value $t$ table (1.72). However, the variables affecting the export of goods and services to value added services sector as the count variable $\mathrm{t}$ exports of goods and services (1.70) approaches the table $\mathrm{t}(1.72)$.

The regression analysis of the principles as set out in Table 4 above shows that all variables GDP per capita, the variable expenditure of government and the variable export of goods and services have a significant impact on the value added agriculture and value added services sector, as shown on the count value $F$ (116.2941 and 72.17347) is greater than the $F$ table (3.47). Please note that the results show the variables GDP per capita government expenditure variables and variables exports of goods and services have contributed substantially to the value added agriculture and services sectors. $\mathrm{R} 2=0.9432$ means that the variable contribution per capita GDP, government spending variables and variable export goods and services to the agricultural sector is 94.32 per cent. While the value of $\mathrm{R} 2=0.9116$ means that the variable contribution per capita GDP, government spending variables and variable export goods and services to the services sector was 91.16 per cent.

Regression analysis showed that the economy, individual ( $\mathrm{t}$ count $>\mathrm{t}$ table) or together $(\mathrm{F}>\mathrm{F}$ table), per capita income and government spending has a significant impact on gross added value of agriculture and the service sector. However, individually, variable export items have no effect on gross added value of the agricultural sector and the services sector $(\mathrm{t}<\mathrm{t}$ table). On the other hand, when jointly, variable per capita income and government spending has a significant effect on gross value added of the agricultural sector and the services sector ( $\mathrm{F}>$ Table F). The study also found that the contribution of these three variables on the base of the gross value added is R2, the gross value added of agricultural sector which is $96.67 \%$, and the gross value added of the services sector was $96.96 \%$ (Appendix 1 ).

Thus, it can be concluded that the export activity is not much to encourage the growth of the primary sector in East Nusa Tenggara Indonesia. This is because there are still many problems, such as overlapping regulations due to high transaction costs, thus reducing the competitiveness of businesses that have been running or even reduce the attractiveness of investments.

\section{Discussion}

Also found that individual changes in a population of less influence on the gross value added sectors of the economy, on the other hand, effects of changes in population and per capita income is very significant to the gross value added economic sectors East Nusa Tenggara Indonesia. This can be seen by the F value for each sector of the economy is greater than the $\mathrm{F}$ table.

This is reinforced by the contribution (R2) of income per capita and total population of the gross value added of the economic sector, which is worth $80 \%$. Based on the analysis concluded elasticity of growth, income per capita or population has the potential to be developed in connection with economic growth of East Nusa Tenggara Indonesia.

Therefore, the results of focus group discussions and indepth interviews found that the basic management of regional economic development plan created by the discussion of all the samples. In addition, specific policies are also sourced to the government office of the regional development planning. These policies include:

1. The investment policy associated with superior products, incentives, and promotions;

2. Basis of regional development, through the identification of determinants and strategies appropriate support;

3. Trade Policy, which trade between regions and sectors, as well as reduce its resistance;

4. Policy development and physical infrastructure, namely human resources;

5. Basic institutional development, including in government decision making mechanism, the creation of regulation, and social and cultural community. 


\section{Conclusions}

One of the indicators of economic development of a region is the GDP. Economic growth in the aggregate may be calculated based on GDP per sector. When a sector has a major contribution and growth is very slow, then it can economic growth in the aggregate. Conversely, when a sector has a relatively large contribution to the economy as a whole, the sector has a high growth rate and thus will be able to benefit economic growth. Regression analysis was used to determine the basic sectors of economy as one the indicators human resources generated by the region.

The successful implementation of economic development plans in region East Nusa Tenggara Indonesia is closely related to the quality of regional development planning. It is implemented based on the identification and characteristics of the area.

It was found also that the economy of East Nusa Tenggara Indonesia theoretically elasticity nature of the changes in per capita income. When there is a change in per capita income by $1 \%$, the change in the gross value added per economic sector is more than $1 \%$. Meanwhile, from the angle of the total population, it was found that the economic sector is elasticity is the agricultural sector, trade, hotels and restaurants, transport and communications, finance, service companies, as well as the services sector.

While four other economic sectors is not elasticity, which means when there is a change of $1 \%$ of the population will lead to changes in gross value added in the four sectors that less than $1 \%$. These sectors are mining and quarrying, manufacturing industry, the electricity, gas and water supply, and construction sector.

\section{Appendix}

\section{Appendix 1. Regression Analysis of Growth and Size Elasticity}

Size growth elasticity analysis is to show a relationship between gross value added due to changes in the economic sector of population and income (GDP) per capita in region. This analysis can then be used to develop projections of economic growth and change or shift in the economic structure of a region. The analysis of data for 25 years (1991 until 2015) using the regression model shows that the value added of each sector the economy in East Nusa Tenggara Indonesia is very much determined or altered individually by changes in income per capita. This is demonstrated by the results of the $t$ test, where the value $t$ table with a $95 \%$ confidence level and degrees of freedom 22 is smaller than the value of variable $t$ per capita income. While variable population of only affect the value added trade, hotels and restaurants and the services sector.

Appendix:2. Gross Value Added and GNP Indonesia at Constant Prices 1997-2013, in the Years $1992-2015$ (Billions of Indonesia Rupiah / IDR)

\begin{tabular}{|c|c|c|c|c|c|c|c|c|c|c|c|}
\hline \multirow{2}{*}{ No } & \multirow{2}{*}{ Years } & \multicolumn{9}{|c|}{ Gross Value Added } & \multirow{2}{*}{ GNP } \\
\hline & & Sector 1 & Sector 2 & Sector 3 & Sector 4 & Sector 5 & Sector 6 & Sector 7 & Sector 8 & Sector 9 & \\
\hline 1 & 1990 & $20,223.50$ & $16,365.50$ & $16,235.30$ & 494.60 & $4,802.90$ & $14,356.20$ & $4,938.50$ & $6,313.20$ & $10,788.20$ & $94,517.90$ \\
\hline 2 & 1991 & $21,213.70$ & $15,892.90$ & $18,182.30$ & 548.90 & $5,259.10$ & $15,656.90$ & $5,211.50$ & $7,514.40$ & $11,501.70$ & $100,981.40$ \\
\hline 3 & 1992 & $21,917.80$ & $16,663.80$ & $19,855.70$ & 615.60 & $5,878.00$ & $17,338.10$ & $5,811.50$ & $2,877.70$ & $12,187.70$ & $103,145.90$ \\
\hline 4 & 1993 & $22,356.90$ & $17,531.70$ & $22,336.90$ & 725.70 & $6,672.90$ & $18,568.60$ & $6,367.90$ & $7,892.60$ & $12,764.10$ & $115,217.30$ \\
\hline 5 & 1994 & $22,657.20$ & $19,341.40$ & $24,481.60$ & 842.80 & $7,475.00$ & $19,572.80$ & $6,869.40$ & $8,680.70$ & $13,243.90$ & $123,164.80$ \\
\hline 6 & 1995 & $24,003.70$ & $19,064.50$ & $26,856.10$ & 928.20 & $8,171.00$ & $21,029.70$ & $7,595.00$ & $9,507.10$ & $13,753.50$ & $130,908.80$ \\
\hline 7 & 1996 & $58,963.40$ & $31,497.30$ & $73,556.30$ & $3,290.20$ & $22,512.90$ & $55,297.60$ & $23,248.90$ & $28,047.80$ & $33,361.40$ & $329,775.80$ \\
\hline 8 & 1997 & $59,291.20$ & $33,261.60$ & $82,649.00$ & $3,702.70$ & $25,857.50$ & $59,504.10$ & $25,065.80$ & $30,901.00$ & $34,285.10$ & $354,518.00$ \\
\hline 9 & 1998 & $61,885.20$ & $35,502.20$ & $91,637.10$ & $4,291.90$ & $29,197.80$ & $64,230.10$ & $27,328.60$ & $34,313.00$ & $35,405.70$ & $383,791.60$ \\
\hline 10 & 1999 & $63,742.60$ & $37,568.60$ & $102,259.70$ & $4,840.50$ & $32,923.70$ & $69,372.00$ & $29,701.10$ & $37,400.60$ & $36,610.20$ & $414,419.00$ \\
\hline 11 & 2000 & $64,468.00$ & $38,538.20$ & $107,629.70$ & $5,479.90$ & $35,346.40$ & $73,523.80$ & $31,782.50$ & $38,543.00$ & $37,934.50$ & $433,246.00$ \\
\hline 12 & 2001 & $63,609.50$ & $37,474.00$ & $95,320.60$ & $5,646.10$ & $22,465.30$ & $60,130.70$ & $26,975.10$ & $28,278.70$ & $36,475.00$ & $376,375.00$ \\
\hline 13 & 2002 & $65,339.10$ & $36,571.80$ & $98,949.40$ & $6,112.90$ & $22,285.50$ & $60,195.10$ & $26,772.10$ & $26,147.90$ & $37,184.00$ & $379,557.80$ \\
\hline 14 & 2003 & $66,431.50$ & $37,423.20$ & $105,085.10$ & $6,649.50$ & $23,788.80$ & $23,788.80$ & $29,284.00$ & $27,373.50$ & $38,009.60$ & $357,834.00$ \\
\hline 15 & 2004 & $225,685.70$ & $168,244.30$ & $398,323.90$ & $9,058.30$ & $80,080.40$ & $234,273.00$ & $70,276.10$ & $123,085.50$ & $133,957.40$ & $1,442,984.60$ \\
\hline 16 & 2005 & $232,973.40$ & $169,932.00$ & $419,388.10$ & $9,868.20$ & $84,469.80$ & $243,409.30$ & $76,173.20$ & $130,928.10$ & $138,982.30$ & $1,506,124.40$ \\
\hline 17 & 2006 & $243,076.10$ & $168,426.70$ & $441,754.70$ & $10,448.10$ & $90,103.40$ & $256,299.50$ & $84,979.00$ & $140,117.30$ & $144,354.20$ & $1,579,559.00$ \\
\hline 18 & 2007 & $252,952.90$ & $160,655.20$ & $469,118.20$ & $11,066.10$ & $97,466.60$ & $271,176.70$ & $95,772.10$ & $150,935.80$ & $151,435.10$ & $1,660,578.70$ \\
\hline 19 & 2008 & $253,881.70$ & $165,222.60$ & $491,561.40$ & $11,584.10$ & $103,598.40$ & $293,654.00$ & $109,261.50$ & $161,252.20$ & $160,799.30$ & $1,750,815.20$ \\
\hline 20 & 2009 & $262,402.80$ & $168,031.70$ & $514,100.30$ & $12,251.00$ & $112,133.60$ & $312,518.70$ & $124,808.90$ & $170,074.30$ & $170,705.40$ & $1,847,026.70$ \\
\hline 21 & 2010 & $271,401.20$ & $171,422.10$ & $538,084.60$ & $13,517.10$ & $121,901.00$ & $338,807.20$ & $142,327.20$ & $183,659.30$ & $181,972.10$ & $1,963,091.80$ \\
\hline 22 & 2011 & $284,337.80$ & $172,300.00$ & $557,765.60$ & $14,993.70$ & $130,815.70$ & $363,314.00$ & $166,076.80$ & $198,799.60$ & $193,700.50$ & $2,082,103.70$ \\
\hline 23 & 2012 & $295,883.80$ & $180,200.50$ & $570,102.50$ & $17,136.80$ & $140,267.80$ & $368,463.00$ & $192,198.80$ & $209,163.00$ & $205,434.20$ & $2,178,850.40$ \\
\hline 24 & 2013 & $304,777.10$ & $187,152.50$ & $597,134.90$ & $18,050.20$ & $150,022.40$ & $400,474.90$ & $217,980.40$ & $221,024.20$ & $217,842.20$ & $2,314,458.80$ \\
\hline 25 & 2014 & $315,036.80$ & $189,761.40$ & $633,781.90$ & $18,921.00$ & $159,993.40$ & $437,199.70$ & $241,298.00$ & $236,146.60$ & $232,537.70$ & $2,464,676.50$ \\
\hline 26 & 2015 & $327,549.70$ & $192,585.40$ & $670,109.00$ & $20,131.40$ & $171,996.60$ & $472,646.20$ & $265,378.40$ & $253,022.70$ & $244,719.80$ & $2,618,139.20$ \\
\hline
\end{tabular}

Information: Sector 1: Agriculture; Sector 2: Mining and Quarrying; Sector 3: Manufacturing; Sector 4: Electricity, Gas and Water Supply; Sector 5: Building and Construction; Sector 6: Trade, Hotel and Restaurant; Sector 7: Transport and Communications; Sector 8: Finance, Leasing and Services; Sector 9: Services 


\section{References}

[1] Aba, F. X. L., Yussof, O. M., Saidatulakmal, B. M. (2015). Analysis of Economic Structure in Poverty Eradication in the Province Of East Nusa Tenggara Indonesia', Journal Procedia - Social and Behavioral Sciences Volume 211, 25 November 2015, Pages 81-88.

[2] Anderson A, Wever E. (2003). Borders, Border Regions and Economic Integration: One World, Ready or Not'. Journal of Borderlands Studies 18 (1): 27-38.

[3] Arthur, W. B. (1994). Increasing Returns and Path Dependency in the Economy', Ann Arbor: University of Michigan Press.

[4] Ayres, I., Raseman, S., Shih, A. (2013). 'Evidence fromTwo Large Field Experiments that Peer Comparison Feedback Can Reduce Residential Energy Usage'. J. Law Econ. Org. 29 (5), 992-1022.

[5] Barro, R. J. (1990). Government Spending in a Simple Model of Endogenous Growth', Journal of Political Economy, 98, S103-S125.

[6] Center Board of Government Statistic. (2006 until 2015). East Nusa Tenggara Indonesia in Figures'.

[7] Chellappa, R., and N. Saraf. (2010). A Study of Alliances and Firm Performance in Enterprise Systems Software Markets: A Social Network Approach', Information Systems Research, 21:4.

[8] Erickson, R. A. (1994). Technology, Industrial Restructuring and Regional Development, Growth and Change', 25, 353379 .

[9] Erickson, R. A., Leinbach, T. (1979). Characteristics of Branch Plants Attracted to Non metropolitan Areas' In: Lonsdale, R., Seyter, H. L. (Eds.): Non metropolitan Industrialisation, Winston, Washington, DC.

[10] Grossman, G. M., Helpman, E. (1991). Innovation and Growth in the Global Economy', MIT Press, Cambridge, MA.

[11] Karlan, D., Morten, M., Zinman, J. (2013). A personal touch: Text messaging for loan repayment'. Working paper.

[12] Krugman, P. 1981, 'Trade, accumulation, and uneven growth', Journal of International Economics 8, 149-161.

[13] Norton, R. D., Rees, J. (1979). The Product Cycle and the Decentralization of North American Manufacturing', Regional Studies.

[14] Powell, Walter W., K. W. Koput, J. I. Bowie, and L. SmithDoerr. (2002). The Spatial Clustering of Science and Capital: Accounting for Biotech Firm-Venture Capital Relationships', Regional Studies 36 (3): 291-306.

[15] Rebelo, S. (1991). Long Run Policy Analysis and Long Run Growth', Journal of Political Economy, 98, S71-S102.

[16] Romer, P. M. (1986). Increasing returns and long-run growth', Journal of PoliticalEconomy, 94 (5) pp. 1002-1037.

[17] Rostow, W. W. (1960). The Stages of Economic Growth: A Non-Communist Manifesto', Cambridge.

[18] Stango, V., Zinman, J. (2014). Limited and Varying Consumer Attention Evidence from Shocks to the Salience of Bank Overdraft Fees', Rev. Finance. Stud. 27 (4), 990-1030.

[19] Stillwell, F. (1992). Understanding Cities and Regions', NSW, Pluto Press.

[20] Stimson, R. J., R. R. Stough, B. H. Roberts. (2006). Regional Economic Development: Analysis and Planning Strategy', Revised Edition., Berlin, Springer.

[21] Thomas, M. D. (1975). Growth Pole Theory, Technological Change and Regional Economic Growth', Papers of the Regional Science Association, 34, 3-25. 